\title{
Social Equity and Large Mining Projects: Voluntary Industry Initiatives, Public Regulation and Community Development Agreements
}

\author{
Ciaran O'Faircheallaigh
}

\begin{abstract}
Large mining projects can generate highly inequitable outcomes, with affected communities bearing the burden of social and environmental costs while economic benefits accrue largely to domestic and foreign metropolitan centres. This raises important ethical and social justice issues, as does the finite nature of mineral resources, which can mean that current generations enjoy the benefits of mining while future generations bear the costs of environmental and social impacts that can continue long after mining ends. During recent decades two broad approaches, voluntary industry initiatives and government regulation, have been employed in attempts to achieve a more equitable distribution of mining's positive and negative effects. Both have serious drawbacks. Industry initiatives are ultimately voluntary and may be abandoned in tough economic times; they can be highly variable across companies and projects; and they suffer from serious compliance issues. Public regulation can be inflexible, is subject to industry capture, and in many major mineral producing nations a 'retreat from regulation' is reducing its relevance. This article considers whether, and under what conditions, a third and emergent instrument, community development agreements (CDAs), can help overcome the shortcomings associated with industry initiatives and public regulation. It argues that CDAs have considerable potential in this regard, but that communities can encounter significant practical challenges in their negotiation and implementation. In addition, disparities in negotiation power between communities and project developers can result in inequitable agreements, indicating a continued need for government involvement to create a more level 'negotiation terrain'.
\end{abstract}

\section{Keywords}

Corporate social responsibility; public regulation; community development agreements; social justice; mining industry 


\section{Introduction}

Almost every corner of the globe is feeling the impacts of extractive industries, as they expand to feed growing demand, especially from China and India, and as technical progress renders it possible to exploit previously-uneconomic resources. ${ }^{1}$ Modern mining projects are highly capital intensive, requiring massive investment but generating relatively few jobs. They create significant environmental impacts because they operate on a huge scale, requiring the mining and processing of millions of tonnes of material each year, generating large quantities of waste, absorbing extensive areas of land and using huge quantities of water. Their social and cultural impacts on neighbouring communities can also be serious and long-lasting, as a result for instance of their effect on existing livelihoods, in-migration caused by the lure of high incomes, and rising social inequality. The result is that economic benefits accrue largely to the corporations that provide the required investment and the national governments that tax them, while local communities frequently bear the brunt of environmental and social costs (Alami 2014; Dougherty and Olsen 2013, p. 2; Sawyer and Gomez 2012).

Mineral resources are finite, and once exploited are lost to future generations. In the absence of measures to extend the economic benefits of resource exploitation beyond mine closure, future generations will not share in the wealth created by their extraction. On the other hand the environmental impacts of large-scale mining can be long lived and so continue to be borne by future generations, for example where they re-shape landscapes or continue to release pollutants after mining ends.

The global spread of extractive industries raises in sharp relief social justice issues that have been central to public policy debate in mineral-rich regions and countries for decades: How is it possible to ensure that the communities most directly affected by mining share in its benefits and are spared at least the worst of its negative effects? How can equity be achieved between generations, so that future as well as current generations benefit from finite resources, and that future generations are not left to cope with environmental damage left behind by mining?

In recent decades and reflecting wider debates on the social effects of business, these questions have been addressed in two main ways, industry initiatives and public regulation (Deegan and Shelley 2013; Eberlein and Matten 2009; Hart 2010). ${ }^{2}$ The former are designed to spread the benefits of mining and minimise its negative impacts and occur either at the level of the firm, referred to here as 'corporate social responsibility' (CSR), or through 
initiatives sponsored by national or international industry bodies or financial institutions that finance resource projects. A fundamental problem is that such initiatives are ultimately voluntary, may be abandoned or diluted due to changing corporate ownership or shifting economic conditions, and are susceptible to major problems of enforcement. As a result, while they are capable of generating significant benefits, these initiatives offer little certainty to host countries and communities that the benefits of mining will be shared, and its impacts managed, especially over the longer term. To the extent they minimise environmental impacts, corporate initiatives can reduce the costs experienced by future generations, but they offer little in terms of ensuring that the depletion of non-renewable resources creates future as well as current economic benefits.

The efficacy of public regulation in addressing the environmental and other impacts of industrial development is the subject of extensive debate. Regulation has resulted in major, industry-wide improvements in environmental standards, and can counter the uncertainty associated with voluntary initiatives. On the other hand regulation can be inflexible and unresponsive, especially to the specific circumstances of communities and regions. Indeed the failure of national regulators to consider local interests lies behind some of the most catastrophic social and environmental impacts of mining (see for instance Denoon 2000). Regulatory regimes can frequently suffer from industry capture, and the contemporary political reality is that in a number of major mining nations, including Australia, Canada and Brazil, national and sub-national regulatory regimes for mining are being wound back and in some cases dismantled. This is occurring as part of a wider 'retreat from regulation' that reflects both the influence of neo-liberal ideology and industry pressure to 'streamline' (i.e. speed up) project approval processes, particularly in the wake of the Global Financial Crisis (de Rijke 2013; Salomans and Hoberg 2013).

This article considers a third and emergent approach, involving the negotiation of contractual agreements between project developers and communities affected by mining, referred to here as 'community development agreements' (CDAs). CDAs can potentially help avoid the essentially discretionary nature of CSR and industry initiatives, counter the inflexibility that can be associated with regulatory approaches, and supplement the increasingly 'hands off' approach of many governments to environmental and industry regulation. CDAs are not proposed here as an alternative to CSR or public regulation, but rather as a powerful mechanism for enhancing the efficacy of industry initiatives and regulation in bring about positive and equitable outcomes for communities affected by extractive industry. CDAs can ensure that affected communities share in the economic 
benefits of mining; help minimise its negative and social effects; and, where they include provision for establishment of long-term investment funds, can provide a foundation for achieving inter-generational equity. However if CDAs are to contribute to equitable outcome, communities need the support of industry and government in creating negotiation frameworks which allow communities to achieve some equality in bargaining power with project developers.

In order to better define the problem that CDAs need to address, the next two sections outline issues surrounding voluntary industry initiative and regulatory approaches to the extractive industries. The following sections provide information about the nature and content of CDAs, and addresses key questions in relation to them: Does current practice in the extractive industries suggest that CDAs can achieve more equitable outcomes from exploitation of finite mineral resources? If CDAs are to do so, what essential features must they display? What challenges arise in negotiating agreements that contain these essential features, and how can government regulators and corporations help address these challenges?

\section{Voluntary industry initiatives}

The first level at which voluntary initiatives occur involves commitments by individual companies to take measures, beyond those required by law, in order to enhance the benefits of their operations and reduce their negative consequences. ${ }^{3}$ All major extractive industry firms now make such commitments. For example Royal Dutch Shell (RDS) aims:

... to have a positive effect in the communities where we operate. We do this by working closely with our neighbours to create jobs and opportunities and develop community programmes. We also work to incorporate local views more effectively into our projects and decision making ... we work to reduce our impacts. This includes helping to conserve the traditional way of life of Indigenous peoples ... (RDS 2011, p. 5; see also BHPBilliton 2012; Xstrata 2013).

In addition to seeking to maximise the benefits generated by its operations, Shell invests substantially (about US\$125 million in 2011) in 'voluntary social investments' in countries where it operates, often in areas with no direct link to its business. Shell also undertakes extensive initiatives with local community groups and national and international environmental non-government organisations, often to an extent not mandated by national environmental regulations, to minimise the environmental impact of its operations and more generally to enhance environmental knowledge and biodiversity (RDS 2011, p. 8). 
Given the scale at which many extractive firms operate and the level of their social investments, CSR initiatives have the potential to generate substantial benefits for affected communities and to minimise negative social and environmental impacts. However a significant limitation of CSR initiatives is the absence of any mechanism to allow communities or public interest groups to enforce company commitments. The result in some cases may be a substantial gap between rhetoric and delivery, and a failure to deliver any substantial economic benefits or improved environmental or social outcomes on the ground (Hilson 2013; Sarker 2013). For example the Canadian-based mining company Hudbay Minerals espouses a commitment to protection of Human Rights, stating:

Hudbay’s Human Rights Policy clearly articulates our commitments to human rights. Key aspects include commitments to practicing ethical business practices, respecting rights of labour practices and labour relations and promoting and welcoming community participation ... (Hudbay Minerals 2013).

Yet Hudbay is currently facing legal action in the Superior Court of Ontario by Mayan people who assert that private security forces hired by Hudbay engaged in numerous human rights violations, including killing and rape, at its Guatemalan operations in 2009 (for details see Superior Court of Ontario 2012). Another example involves the major energy producer and distributor, Enbridge. Enbridge states that it is 'fully committed' to developing a strategic approach to environmental management, an approach that the company says 'benefits all of Enbridge's stakeholders and society at large' (Enbridge 2013). But in conducting impact assessments for a proposed oil pipeline across northern British Columbia, Enbridge's analysis of a key environmental issue, the ability of a caribou herd to cope with the pipeline's impact, was not, as the company implied in its submission to the environmental review panel assessing the pipeline, based on peer-reviewed scientific evidence. Rather it was based on a single slide show about another caribou herd in Canada's Yukon Territory, where the ecological context and existing industry impacts were very different (Hume 2012).

A further problem is that companies may abandon CSR initiatives and extraregulatory environmental activities as a result of change in company ownership, the changing priorities of a new CEO, or shifts in economic conditions (Goodland 2012). This reflects the essentially instrumental nature of CSR initiatives and the consequent tendency of firms to pursue cost-minimisation strategies (Hart 2010, 586-87). For example a number of companies in Australia have severely curtailed their community engagement activity as a result of the recent deterioration in commodity prices. Communities have no mechanisms at their disposal that would allow them to prevent such changes and the negative consequences they bring. 
There can be consequences for company failure to honour existing commitments or dilute CSR policies in terms of 'community backlash' and negative publicity. Yet at their core CSR commitments are essentially voluntary (Sarker 2013, p. 7; RDS 2011, p. 5), and as such can offer communities little assurance that their interests will be protected, particularly over the longer term.

A second level of industry-based initiatives involves national industry bodies such as the Minerals Council of Australia; international industry associations, for example the International Council on Mining and Metals (ICMM); and banking institutions that provide finance for extractive industries, for instance the International Finance Corporation (IFC) and the Equator Principles Financial Institutions. These entities are increasingly active in establishing guidelines and standards which, if complied with, could certainly enhance the role of communities in planning resource projects, the efficacy of environmental management systems, and the economic benefits accruing to communities. For instance the ICMM's 'Good Practice Guide: Indigenous Peoples and Mining' requires extensive engagement with affected Indigenous people from early in project life and conducted with respect for traditional decision-making processes; projects to be designed to avoid or mitigate negative impacts; and a range of initiatives to generate benefits for local communities, including employment and income-earning opportunities (ICMM 2011). The IFC's Performance Standards 2012 imposes extensive obligations on IFC clients to pursue environmental and social sustainability, including by ensuring their operations apply non-discriminatory employment practices; avoid or minimise pollution; create net gains in biodiversity values; and only proceed with development with the Free Prior Informed Consent of affected Indigenous people where projects require relocation of Indigenous people or have significant impacts on their 'critical cultural heritage' (IFC 2012).

Such initiatives can be valuable in establishing standards for corporate behaviour in dealing with communities, especially because companies find it difficult to contest their legitimacy, given that they emerge from industry bodies in which companies are involved or from banks which help fund their investments. However problems arising from the voluntary nature of initiatives and the absence of enforcement mechanisms are compounded at this level. Relevant standards often serve only as 'guides' which companies are not obliged to comply with (Sarker 2013, p. 5). A possible exception is the IFC Performance Standards, which are mandatory for projects the IFC helps to finance and where affected communities have access to a Compliance Ombudsman Advisor if they believe that projects have not complied with the Performance Standards or have adversely affected them (COA 2012). 
However many of the Performance Standards are in effect discretionary because of the wording they use, or are qualified in ways that create a capacity for project operators to contest claims of non-compliance. For example, in some cases clients need only 'consider' applying certain measures; in others, objectives (for instance the requirement to achieve no net loss of diversity) apply only 'where feasible', and there could clearly be disagreement about what is or is not feasible. Similarly, the issue of whether or not Indigenous heritage is 'critical' and so requires application of FPIC could be contested (IFC 2012a). These features of the Standards could make it difficult for communities to prosecute a successful complaint with the Compliance Advisor Ombudsman. It is also unclear what action the IFC would take if a complaint was upheld and dispute resolution failed or, more generally, if the IFC found that a client was in breach of the Standards and failed to remedy that breach. The IFC states it would 'exercise its rights and remedies, as appropriate' (2012b, p. 5), but it is not clear from public documents what this would involve, or whether the IFC has followed this course of action in relation to any of its investments.

The World Bank Policy on Indigenous People (World Bank 2013) provides a graphic illustration of the limitations of financial institution initiatives. The Policy states that bankfinanced projects include 'measures to (a) avoid potentially adverse effects on the Indigenous Peoples’ communities; or (b) when avoidance is not feasible, minimize, mitigate, or compensate for such effects'; and that projects are designed 'to ensure that the Indigenous Peoples receive social and economic benefits that are culturally appropriate and gender and intergenerationally inclusive'. In pursuit of these goals, the Policy requires potential borrowers to undertake impact assessments of proposed projects and, based on these assessments, to develop an Indigenous Peoples Plan that sets out measures 'to ensure that Indigenous Peoples affected by the Project receive culturally appropriate social and economic benefits, and to avoid, minimize or compensate for any adverse effects on Indigenous people'. Borrowers must also demonstrate that there is 'broad community support' for the proposed project (World Bank 2013, Clauses 1, 6, 9, and 12).

In 2011 the World Bank’s Quality Assurance and Compliance Unit undertook a Review of the Implementation of the Bank’s Indigenous Peoples Policy over the period 2006 - 2008 (World Bank 2011). It demonstrated major shortcomings with the policy and its implementation. For example, impact analysis was not done well in about half of projects. A common shortcoming was that no negative impacts on Indigenous Peoples were mentioned, an omission deemed particularly striking in projects that mention risk factors which, by definition, would generate negative impacts if risks materialize. While projects might 
consider short-term positive or negative impacts, they usually failed to consider the long-term impacts that project interventions could have on the livelihood, social organization and cultural integrity of Indigenous Peoples. Very few projects included monitoring indicators specifically designed to measure project performance regarding Indigenous Peoples. In many of the projects reviewed, Indigenous Peoples were included as part of general project beneficiaries and it is not possible to determine what benefits, if any, reached them. Broad community support was evidenced in less than half of all projects (World Bank 2011, pp. 2127).

These problems reflect two underlying weakness in the World Bank's approach (for a comprehensive analysis see O’Faircheallaigh 2013a). The first is the absence of any mechanisms allowing for affected Indigenous peoples to themselves negotiate impact assessment and impact management regimes, and mechanisms for provision of community support, that would be acceptable from their point of view. The second is that the World Bank Policy focuses on requirements the lender must meet in order to secure access to World Bank funds, rather than on ensuring that impacts are managed and benefits maximised throughout the whole life of a project.

\section{Public Regulation}

Given that in most countries minerals belong to the State and that states have the primary responsibility for protecting the interests of their citizens, there are powerful arguments for asserting that the principal mechanism for ensuring that communities benefit from mining and are protected from its negative effects should be public regulation. For instance Robert Goodland, a former World Bank advisor, in commenting on corporate initiatives states:

Self-regulation and voluntary compliance are not enough ... voluntary, non-binding and self-reporting standards are not working adequately ... mining improvements are best achieved by mandatory regulations ... and government sanctions for violations (Goodland 2012: 17).

Given the discussion of voluntary initiatives, Goodland's position appears sound in principle. However public regulation has been subject to extensive criticism in recent decades on the basis that it involves centralized, bureaucratic standard setting which is inflexible, inefficient, cumbersome and excessively costly for industry; is ineffective because of inadequate government funding, a reluctance by authorities to prosecute and by courts to impose maximum penalties; and fails to provide incentives for industry to exceed minimum, 
'compliance' outcomes required by regulation (Andrews 1998; Cunningham and Sinclair 1999, 49-500, 70-71; Kagan, Gunningham and Thornton 2003; Sinclair 1997; Van Rooij 2010; Wright and Head 2009, 192-193).

'Regulatory failure' or 'regulatory capture' is another major issue, with the risk that regulatory bodies develop close relations with industry and fail to protect the public interest. For example in oil- and gas-rich Alberta, the Provincial Energy Resources Conservation Board is required under its legislation to 'consider the public interest' in making decisions on whether to grant energy project licence applications. Yet Fluker (2011) shows that the Board grants virtually all applications, most of them 'solely on the basis of information provided by the applicant company', and is reluctant to allow public participation in its decision making. Indeed Fluker concludes that 'it is difficult to comprehend how the ERCB complies with its statutory obligations' (2011, p. 5) and that 'it is debatable whether the Board engages in public participation at all’ (2011, p. 2).

These criticisms of public regulation have led to calls for a move towards industry self-regulation, voluntary industry initiatives, market mechanisms and public and industry educational initiatives (Andrews 1999; Van Rooij 2010). These alternative approaches also have inherent problems, including their lack of reliability, their inability to bring about major, industry-wide improvements in overall standards of environmental management, and the absence of the industry and state governance capacities required to implement them effectively (see previous section, and Gunningham and Sinclair 1999; Van Rooij 2010). Recognition of the shortcomings of both 'command and control' and 'voluntary/selfregulatory' approaches have led to calls for 'regulatory pluralism', for a pragmatic approach designed to combine a range of regulatory and governance arrangements (Gunningham and Sinclair 1999; Wright and Head 2009). Empirical research tends to support such an approach. For instance Kagan, Gunningham and Thornton’s (2003) comparative cross-national study found that the environmental impacts of pulp and paper mills were determined by a combination of regulatory regimes, firm level economic incentives, political and social pressures and corporate approaches to environmental management. Wright and Head (2009) came to similar conclusions in the very different context of regulation of the gambling industry in Australia.

These findings suggest that CDAs may have a valuable role to play in augmenting public regulation of extractive industries, for example as a channel for mobilisation of 'political and social pressures' at the community level, and for engaging with industry in a manner that influences corporate approaches to environmental management. 
Contemporary political realities suggest that the role of CDAs in augmenting public regulation may in fact be vital. In many major mineral producing countries, key components of the regulatory system for extractive industries, and in particular environmental regulation, are being dismantled. Increasingly, public regulation seems likely to be ineffective simply because it will not exist. For example, Canada’s Federal Government has recently dismantled much of the legislative and regulatory system under which large resource projects were assessed and, if approved, regulated in relation to their environmental and social impacts (Gibson 2012). Canada has also severely curtailed the activities of Fisheries and Oceans Canada, an agency which played a key role in monitoring the environmental impacts of major projects, reducing its regional offices from 63 to 15 and cutting its frontline staff; and substantially reduced opportunities for public participation in environmental decisionmaking, in part by withdrawing funding to support intervention by community or nongovernment organisations (McLeod 2012). Much of this change has been effected through omnibus budget bills which limit the opportunity for public debate (Kirchhoff and Tsuji 2014).

In Australia the conservative Federal Government elected in 2013 is delegating much of the responsibility for environmental regulation to state governments, but at the same time states have been dismantling large parts of their own their own environmental management regimes, effectively creating a vacuum in environmental regulation (Caripis 2013; Godden, Peel and Caripis 2012). For example Queensland, one of Australia’s largest mining states, has eliminated 1,400 jobs across government departments dealing with environmental regulation, including those of 30 inspectors whose role was to check on resource development projects with environmental conditions attached. It has revoked legislation to protect 'wild' (i.e. unharnessed) rivers; withdrawn funding from the state's Environmental Defenders Office; ended access to the judicial system for members of the public who believe that environmental laws have been breached; and removed any appeal rights or statutory judicial review of government decisions on the largest development and mining projects (Collins 2012; Environmental Defenders Office Queensland 2014; Schneiders 2013). Similar trends are evident at the provincial level in Canada. For example environmental enforcement activities have declined sharply in Alberta's oil sands industry (by almost a third between 2010 and 2012) (Nwapi 2012).

The 'rolling back' of public regulation of the environment is evident across the globe (Goodland 2012, Hart 2010), as indicated for example by developments similar to those in Australia and Canada in the United States (Steinzor, Glicksman and Havemann 2014), Brazil 
(Novaes and de Franca Souza (2013) and Sub-Saharan Africa (Campbell 2009). These developments can be seen as reflecting the current dominance of neo-liberal ideology which posits that market forces should determine social and political outcomes, that corporations should be allowed maximum freedom, and that the State should reduce its role in the economy and in particular should minimise industry regulation (Hickel 2012). The 'retreat from regulation' associated with neo-liberal policies has important implications for the outcomes from large-scale extractive industries. As noted earlier, their environmental impacts are felt disproportionately by adjacent communities, and if nothing is done to minimise those impacts or compensate for them, extractive industries are likely, as has occurred in the past, to generate profoundly inequitable outcomes. CDAs may have the potential to at least mitigate such outcomes if they allow communities to negotiate legally enforceable measures to manage the environmental and other impacts of extractive projects.

\section{Community Development Agreements}

\section{What are CDAs?}

CDAs are defined here as formal agreements between developers (private or public) and community representatives or organisations. They are designed to minimise negative project impacts and ensure that local communities obtain benefits from development they would not enjoy in the absence of agreements, thus helping to reduce or eliminate conflict surrounding development.

A key definitional issue involves the concept of 'community', which can be problematic and open to a range of interpretations. In the context of a CDA, 'community' usually has one of two meanings. The first refers to people residing in a location adjacent to, or affected by, a mining project. They share a place of residence and an experience of impact, though the nature of that experience may differ between individuals and groups within a community. The second refers to people (frequently Indigenous) who share economic, cultural and social ties, through their association with an area of land or water affected by mining. They may not reside in one place, and indeed may be widely dispersed. Yet they represent a social and cultural community and, again, an experience of impact, though in this case also the nature of that impact may be diverse. In many cases a mining project affects a number of overlapping ‘communities of people’ of both types. 
Use of the term 'community' in either of the two senses just discussed does not imply a single attitude or approach to mining or to negotiation of CDAs among community members. Indeed many communities are divided in relation to mining, and political contests around distribution of benefits provided by CDAs can sharpen existing community divisions or give rise to new ones (Bainton 2010; Sawyer and Gomez 2012).

There has been a veritable explosion of CDAs in recent decades, both geographically and across industry sectors. This reflects a range of factors, including the need to minimise conflict around projects by achieving a more equitable distribution of costs and benefits at local and regional levels; to help address the tension between pursuit of socio-economic development and protection of the cultural and bio-physical environments; and to help deal with issues in relation to inter-generational equity associated with exploitation of finite mineral deposits (see O’Faircheallaigh 2013b for a detailed discussion).

An additional reason for the rapid growth in CDAs raises the central concern of this article. CDAs may constitute a policy instrument that allows some significant weaknesses of both voluntary industry initiatives and public regulation to be addressed. CDAs are usually contracts and so are legally binding. ${ }^{4}$ At least in principle, therefore, the commitments of project developers are not voluntary and cannot be abandoned on the basis of changes in corporate ownership, policies or priorities. In most cases CDAs include communities or their representatives as parties, and so their negotiation, implementation and enforcement do not depend on the willingness of governments and public regulators to commit public funds or to take an assertive stand in relation to powerful resource industries. In addition, because they are negotiated by communities, CDAs seem more likely than national or sub-national legislation and policy to prioritise local interests and priorities. Finally, given that their content is essentially a matter to be determined by the parties, they should allow for a high degree of flexibility in the management of projects and distribution of their benefits.

The following sections identify key issues that determine whether the potential of CDAs to address weaknesses in voluntary initiatives and public regulation is likely to be realised in practice.

\section{The Content of CDAs}

As noted below, the content of CDAs vary considerably because, as negotiated agreements, they are highly adaptable to local circumstances and priorities. However CDAs generally provide community consent or support for proposed or existing industrial or commercial 
activity, in return for a package of community benefits and impact mitigation measures. Benefits can include preferential access for community members to employment opportunities, and training programs to enhance their 'employability'; participation of local businesses in contracting opportunities; and, especially in the case of extractive industries, a revenue stream for the community related to the scale of the operation concerned and/or its profitability. Impact mitigation measures can focus on management of population inflows caused by a project; protection of a community's cultural heritage; and community participation in environmental decision making and environmental management.

The last is of particular interest given the current widespread tendency for state authorities to reduce their involvement in environmental regulation. CDA provisions can include a legal right for the community to seek court action to enforce environmental laws if these are not being enforced by public regulators; community participation in environmental planning (including planning for project closure), in environmental permitting, and in environmental monitoring and management programs; and, in some cases, joint decisionmaking by project operators and community representatives on key environmental issues. Some more recent CDAs on Indigenous lands in Australia and Canada also provide for project operators to maintain environmental insurance policies whose proceeds are available for remediation work if projects cause significant environmental damage (Gibson and O’Faircheallaigh 2010, 160-163).

\section{Enforcement and certainty}

As noted above, given that CDAs are contracts, parties are legally obliged to deliver commitments they make in agreements and can be subject to court action if they fail to do so. In practice matters may be more complex. Obligations or commitments need to be expressed in language that makes them susceptible to enforcement by the courts. Like the IFC Performance Standards, agreements in fact often contain language ('where possible', 'where practicable', 'make best endeavours') that make it difficult to show definitely that an agreement has been breached. It is hard, for instance, to show conclusively that a party has not made its 'best endeavours' to achieve a particular goal, for example in relation to employment of local people. Expression of agreement goals in broad terms (for example 'maximise employment of local people', 'maximise Indigenous business opportunities') creates similar problems. It is therefore essential that the language used in CDAs is plain, 
unequivocal, and direct, and that goals are stated in as much detail as possible and have specific time frames attached to them.

Even where agreement breaches are unequivocal, communities may lack the financial and technical resources to successfully prosecute legal action, and legal regimes, like regulatory ones, may be unreceptive or even hostile to local perspectives and interests. Communities may also be unwilling to take legal action, because they do not want to threaten relationships with project operators that, while problematic in some areas, are generating significant benefits in others. These benefits may not be linked to agreements and, in reality, may not be vulnerable to community action to enforce agreements, but communities may nevertheless be reluctant to 'make waves'. I am aware of one Canadian community, for example, that recently refrained from taking action on a problem in relation to financial provisions of a CDA because a number of major local employers were heavily dependent on contracts from the project involved. This discussion raises important issues about the relative power of parties to CDAs, an issue to which we return.

Against this background, it is essential that, to the extent possible, agreements contain mechanisms that ensure automatic responses in situations where commitments are not delivered, preferably of a sort that increase the likelihood that they will eventuate in the future. For example a number of CDAs in the United States and Australia provide that if local employment goals are not achieved, the project operator must pay specified amounts into trust funds dedicated to enhancing the skills of local people, or establishing business enterprises that will generate alternative sources of employment. It is also important to include dispute resolution clauses which are effective in allowing specific issues to be addressed without recourse to legal action, and while agreements continue to operate. Such provisions are often inserted late in agreement making processes and consist of standard, 'boiler plate' clauses rather than arrangements that are designed to be functional for the specific parties involved. Dispute resolution should generally provide for problems to be dealt with as soon as they arise, by company and community representatives with the knowledge and authority to address the issues involved, and provide for early, informal mediation by third parties if a dispute persists.

While recognising the challenges communities face, it is also the case that CDAs are becoming increasingly sophisticated in meeting the requirements for effective enforcement. One area involves community access to information on company and project activities. It is difficult even to know that an agreement is being breached, let alone take action to enforce it, without timely and full access to information. In the environmental area, a number of recent 
CDAs in Australia require the project operator to provide Indigenous communities with access to all environmental reports and applications for environmental approvals when these are lodged with regulatory authorities. They also provide for regular inspections of relevant records and facilities by independent environmental experts funded by the company but selected by and reporting to the community. Another recent and more fundamental innovation, currently restricted to a small number of agreements, is that a community has the power, if it fears that environmental damage is imminent, to require the company to suspend operations until the risk is assessed by independent experts, and remedial action taken, if necessary. The existence of such a power, even if it is rarely or indeed never applied, is likely to obviate the likelihood that environmental conditions will be breached, and so remove the need for legal action after the event.

\section{Implementation}

The problems that have been encountered in putting CDAs into effect, the underlying factors giving rise to them, and the requirements for effective implementation have all been extensively documented and so will not be canvassed here (see for example Gibson and O’Faircheallaigh 2010; O’Faircheallaigh 2002; Langton et al. 2006). Broadly speaking, successful implementation requires inclusion of appropriate provisions in agreements, including clear allocation of responsibilities and allocation of specific funding for implementation activities; measures to address turnover and changing priorities that can affect the commitment of corporate and community leaders to implementation; adaption to changing circumstances; and constant attention to maintaining the company-community relationships that are central to effective implementation. These are demanding requirements that project developers and communities must work hard to achieve.

\section{Maintaining commitments over time}

CDAs can deal with the specific issue of ensuring that obligations are maintained despite changes in corporate ownership. This can be effected through inclusion of an appropriate 'assignment clause', under which the current project owner is legally prohibited from selling its interests in the project until the new owner has signed a deed, in a designated form, agreeing to take on all commitments under the CDA. There is still of course the issue of whether a new owner has the commitment required to pursue the spirit of a CDA rather than the letter of its legal obligations. There is also the wider question, which applies even if there 
is no change of ownership, of whether both corporate and community commitment to an agreement can be maintained over the longer term. Personnel changes, the demands of other issues, and loss of corporate and institutional memories with the passage of time, all make this difficult. There is a strong argument for using the review procedures included in most CDAs not just as an opportunity to formally review the performance of the parties under the existing agreement, but to renew relationships, refresh memories and consider whether an agreement still meets the needs of the parties.

\section{Intergenerational Equity}

Where CDAs generate revenue streams from mining projects, they have the potential to address issues of intergenerational equity through the establishment of long-term investment funds. These allow affected communities to build up a capital base while mining is underway, and use this to generate an ongoing income stream after it ends. This income can be used both to address any social and environmental impacts that remain after projects have been abandoned by their operators, and to ensure that community members continue to derive social and economic benefits from finite resources that have been depleted by mining. They constitute a 'community level' equivalent of the Sovereign Wealth Funds established by a number of major oil and mineral producing countries in an attempt to extend the benefits of resource exploitation and achieve intergenerational equity at the national level (Yi-chong and Bahgat 2010).

For example, when the Aboriginal Traditional Owners of the Weipa Bauxite mine in North Queensland signed a CDA with the mine operator, Rio Tinto Aluminium, in 2001, they decided to invest 60 per cent of the annual payments they receive under the agreement in a long-term investment trust. The capital of the trust is preserved, and all income from it reinvested in the trust, for 20 years. At the end of the 20 years, the same proportion of annual payments made under the CDA continue to be invested in the fund, but income from the fund becomes available for allocation to current expenditures. At the end of the 20 year 'income reinvestment' period the trust will have a significant capital base which will generate an income for Traditional Owners well into the future and possibly long after mining has ceased. Similar trusts have been established under CDAs negotiated elsewhere in North Australia and in northern Canada.

\section{Adaptability to Local Conditions}


The huge variety of provisions included in CDAs, even where they are negotiated under a single legislative regime, bear testimony to the flexibility of CDAs. This reflects the fact that, even in situations where the conclusion of a CDA is a legal requirement, it is usually left to the parties to determine its content. ${ }^{5}$ This variability suggests strongly that CDAs at least have the potential to address the issues that are of critical importance in specific local contexts. Whether that potential is realised depends on two key factors - the nature of community representation and the extent to which CDA negotiators pursue community interests; and the bargaining power of communities, and their consequent capacity to ensure that their goals are reflected in CDAs.

The legitimacy of community representatives and their capacity to articulate and promote the full range of community interests is critical to the success of CDA negotiations and the sustainability of agreements. Exclusion of whole communities or of groups within communities affected by a project can result in important issues not being pursued in negotiations. In the longer term it can also generate ongoing social tensions, undermine agreements, and result in a failure to realise the benefits they potentially offer (CSRM 2011; Lowe and Morton 2008). The practice of some companies and state agencies of engaging with community members who appear sympathetic to development, or who are easier to engage because of their gender or language skills, can militate against effective and legitimate community representation. On the other hand company efforts to facilitate broadlybased representation can yield dividends in terms of the durability and utility of agreements (ERM 2010).

Communities vary greatly in terms of the approaches they adopt to selecting negotiators and representatives on governing structures established through CDAs, including holding specific elections; nominating local government officials or traditional leaders; or establishing community stakeholder groups which include key demographic or cultural groups, including landowners, women, young people, educators, elders, and business people (for examples see CSRM 2011; O’Faircheallaigh 2000). Obviously what is important is that the approach used results in the effective articulation and pursuit of the full range of community interests.

A more specific issue regarding community representation involves the opportunities created by using broader representative structures that can engage in learning about CDAs and build up institutional memory and accumulate expertise over time. A notable feature of Indigenous CDAs in Australia is that agreements that offer substantial net benefits to landowners and local communities most frequently emerge from negotiations where local 
interests are supported by regional bodies such as Aboriginal land councils. Apart from the fact that these bodies can add to the bargaining power available to local groups (see next section), they can build on the lessons learned in individual negotiations and on precedents established in particular CDAs to design agreements that align closely with local interests and priorities. This process can clearly be seen at work for example in the succession of CDAs negotiated with the support of the Cape York Land Council between 1992 and 2001 (O’Faircheallaigh 2000) and the Kimberley Land Council (KLC) between 2004 and 2011 (KLC 2011).

The second factor affecting responsiveness of CDAs to local interest is community bargaining power, which is of fundamental and wider significance in considering the role of CDAs.

\section{Community Bargaining Power}

CDAs are the outcome of negotiation between the parties to a proposed agreement. Thus the scale of benefits and the efficacy of impact mitigation measures reflect the relative bargaining power of communities and landowners, on the one hand, and project developers on the other. Relative bargaining power reflects, in turn, a wide variety of factors that tend to vary from one context to another. These include the degree of community cohesion and the strength or weakness of local political organisations; the human, financial and information resources available to local communities and organisations; the quality of political leadership; and a community's prior history of dealing with development. They also include the policies and practices of individual developer corporations; expected project profitability; the urgency of project time frames; and relevant legislation and Government policies and actions (or lack of them).

The critical importance of individual negotiation contexts is highlighted by the fact that even where CDAs are negotiated under the same legislative regime, their outcomes can vary dramatically. For example some agreements negotiated under Australia’s Native Title Act 1993 confer on Indigenous communities or landowners a substantial share of project revenues, contain firm commitments on Indigenous training and business development, provide stringent protection for cultural heritage, and afford landowners a central role in environmental management. Other agreements under the same legislation contain minimal economic benefits and offer no mitigation measures beyond what is required by law. These contrasting outcomes reflect the fact that the factors determining relative bargaining power 
can vary greatly from one part of Australia to another, from one community to another, and from one project and one company to another (O’Faircheallaigh 2013b; see also ERM 2010; Sawyer and Gomez 2012).

Where communities effectively exploit a strong bargaining position, CDAs can constitute a basis for redefining the relationship between communities and developers, and for changing the distribution of project benefits and costs in fundamental ways. Where communities are in an inherently weak position or fail to exploit their potential bargaining power, 'win-win' outcomes will not eventuate and indeed CDAs can leave communities worse off than the absence of an agreement. This is because signing a CDA often precludes a community from pursuing other avenues (for example litigation or direct action to oppose development) that might allow it to halt a project which is unlikely to generate net benefits, or to achieve an outcome better than that available from negotiating an agreement. A CDA signed from a weak bargaining position may also create community divisions and will reflect the priorities of the project developer, deflecting a community from its own priorities and undermining its autonomy.

This variability in the negotiating positions of individual communities raises an important issue with CDAs, that they can result in inequitable outcomes between communities experiencing similar impacts from extractive industry activity.

Both corporations and governments can help avoid such outcomes. Corporations can adopt policies that mandate negotiation of CDAs regardless of whether these are required by law, and undertake to fund negotiation of CDAs in ways that minimise the likelihood that corporate funding will be used as a lever to reduce community bargaining power. Rio Tinto, one of the world's largest mining companies, adopted such an approach from the mid-1990s onwards, deciding that it would negotiate CDAs with all Indigenous communities adjacent to its mines regardless of whether there was a legal requirement to do so. Funding was generally provided to communities on the basis of a 'Memorandum of Understanding' which both set out clear rules for provision and use of negotiation funds, and created a 'firewall' between the funder and community negotiators and other support or technical staff, ensuring that the accountability of staff was solely to the community. This approach resulted in negotiation of a series of CDAs providing substantial economic benefits and a major role in environmental management for affected communities (Gibson and O’Faircheallaigh 2010, 81-82; Harvey and Nish 2005).

Governments can assist by mandating the negotiation of CDAs and by providing funding support for communities engaged in their negotiation. A number of comprehensive 
land claim settlements concluded by the Canadian Government with Aboriginal Peoples requires the negotiation of CDAs before any major development projects can proceed. The relevant provisions are not prescriptive in that they leave the scope and content of CDAs open for negotiation. Only the requirement for a CDA is mandated, maintaining the flexibility that must be a central feature of CDAs if they are to reflect the interests and priorities of individual communities (Gibson and O’Faircheallaigh 2010, 32-33).

Corporate and state initiatives of this sort cannot fully address the inequalities of bargaining power, given that to some extent these reflect innate characteristics of particular communities. However they can certainly mitigate such inequalities, and help realise the potential contribution of CDAs in achieving fair and equitable outcomes for communities.

\section{Conclusion}

CDAs can play a key role in augmenting the role of voluntary corporate initiatives and of public regulation in addressing ethical and social justice issues associated with the impact of extractive industries on communities. In relation to corporate initiatives, communities can use CDAs to insist on the performance of corporate commitments and on their maintenance over time and despite changes in corporate personnel, policy priorities and organisational structures. In relation to public regulation, CDAs have the advantage of being highly flexible and adaptable to different circumstances. In addition, they can continue to operate and help mitigate the negative impacts of extractive industries where states choose to dismantle, downsize or otherwise weaken regulatory systems. This latter role may prove to be highly significant, because history suggests that at least in relation to extractive industries such a 'retreat from regulation' will result in growing local resentment against projects that are seen to deliver little for affected communities, leading to a backlash against projects and delays and cost overruns for developers.

In relation to both corporate initiatives and public regulation, a key advantage of CDAs is that communities themselves are 'principals' in negotiations and parties to agreements. Communities do not have to rely on corporations or governments to 'interpret' community interests or priorities, as CDAs can directly reflect the specific interests and concerns of community members.

Where they contain substantial income streams, CDAs also have the potential to address issues of inter-generational equity associated with extractive industries. They can extend the benefits of mining into the future, helping communities to address any social and 
environmental legacies that remain after mining ends and spreading the benefits created by exploitation of finite resources over time.

The practical limitations of CDAs must also be recognised. Their effective negotiation and implementation constitute a major challenge for communities. They must overcome what are often inferior bargaining positions; establish robust representative structures; overcome the substantial problems inherent in implementing agreements; ensure that agreements are drafted in a way that facilitates their enforcement, preferably without recourse to expensive legal processes; and, in relation to major resource projects, maintain their focus and effort on these issues over considerable periods of time. It is inevitable that some communities will be more successful than others in meeting these challenges, resulting in uneven outcomes.

Against this background public regulation and corporate policies have a vital role to play in minimising inequitable outcomes and ensuring that all communities share in the benefits of, and are protected from the impacts of, major resource projects. The creation of a legal requirement for negotiation of CDAs before extractive projects can proceed, and provision of funding for communities to negotiate CDAs through mechanisms that do not undermine their bargaining position, are especially important.

\section{References}

Alami, A. (2014). On Moroccan Hill, Villagers Make Stand Against a Mine. New York Times, 23 January, http://www.nytimes.com/2014/01/24/world/africa/on-moroccanhill-villagers-make-stand-against-a-mine.html? r=0 Accessed 4 February 2014 Andrews, R.N.L. (1998). Environmental regulation and business ‘self-regulation’. Policy Sciences, 31, 177-197.

Bainton, N.A. (2010) The Lihir Destiny: Cultural Responses to Mining in Melanesia. Canberra: Australian National University E Press, Canberra.

BHP Billiton. 2012. Sustainability.

http://www.bhpbilliton.com/home/aboutus/sustainability/Pages/default.aspx. Accessed 26 November 2012.

Campbell, B. (Ed.) (2009). Mining in Africa: Regulation and Development. London: Pluto Press.

Caripis, L. (2013). Victoria law change abandons native forests to loggers. The Conversation, 27 May http://theconversation.com/victorian-law-change-abandons-native-forests-tologgers-14113 Accessed 17 June 2014 
Collins, S-J (2012). Shock and Ore. The Global Mail, 14 December

http://www.theglobalmail.org/feature/shock-and-ore/513/ Accessed 17 June 2014

Compliance Advisor Ombudsman (2012). Annual Report 2012, Office of the Compliance

Advisor Ombudsman http://www.cao-

ombudsman.org/documents/CAOAnnualReport2012.pdf. Accessed 3 February 2014.

CSRM (Centre for Social Responsibility in Mining) (2011). ERM Extractive Industries

Source Book, Good Practice Notes on Community Development Agreements, CSRM, Brisbane. https://www.csrm.uq.edu.au/Portals/0/docs/CSRM-CDA-report.pdf

Deegan, C. \& Shelley, M. (2013). Corporate Social Responsibilities: Alternative Perspectives on the Need to Legislate. Journal of Business Ethics, DOI 10.1007/s10551-013-17302.

Denoon, D. (2000). Getting under the Skin: The Bougainville Copper Agreement and the Creation of the Panguna Mine. Melbourne: Melbourne University Press.

De Rijke, K. (2013). Coal Seam Gas and Social Impact Assessment: An Anthropological Contribution to Current Debates and Practices. Journal of Economic and Social Policy, 15(3), http://epubs.scu.edu.au/jesp/vol15/iss3/3

Dougherty, M.L \& Olsen, T.D. (2013). Taking Terrain Literally: Grounding Local Adaptation to Corporate Social Responsibility in the Extractive Industries. Journal of Business Ethics, 119(3), 423-34.

Eberlein, B. \& Matten, D. (2009). Business Responses to Climate Change Regulation in Canada and Germany: Lessons for MNCs from Emerging Economies. Journal of Business Ethics, 86, 241-55.

Enbridge (2013). 2011 Environmental Performance Overview. http://csr.enbridge.com/TheEnvironment/2011-Environmental-Performance-Overview Accessed 14 January 2013 ERM (Environmental Resources Management). (2010). Mining Community Development Agreements, Final Report for the World Bank, ERM, Washington D.C. http://www.sdsg.org/wp-content/uploads/2011/06/CDA-Report-FINAL.pdf

Environment Defenders Office Queensland (2014). Submission to the Great Barrier Reef Strategic Assessment 31 January 2014. EDOQ http://www.edo.org.au/edoqld/wpcontent/uploads/2014/01/2014-01-31-EDO-Qld-and-EDO-NQ-Joint-Submission-onthe-Draft-GBR-Coastal-Zone-SA-Program-Report.pdf Accessed 14 June 2014

Fluker, S. (2011). Public Participation at the Alberta Energy Conservation Board. Resources, No. 111, 1-8. 
Fuentes, J.R. (2011). 'Learning how to manage natural resource revenue: the experience of copper in Chile'. In P. Collier \& A.J. Venebles (Eds.), Plundered Nations? Successes and Failures in Natural Resource Extraction (pp. 79 - 113). London: Palgrave Macmillan.

Gibson, G., \& O’Faircheallaigh, C. (2010). IBA Community Toolkit: Negotiation and Implementation of Impact and Benefit Agreements. Toronto: Walter \& Duncan Gordon Foundation.

Gibson, R. (2012). In full retreat: The Canadian government's new environmental assessment law undoes decades of progress. Impact Assessment and Project Appraisal, 30(3), 179-188.

Godden, L., Peel, J. \& Caripis, L. (2012). Commonwealth should keep final say on environment protection. The Conversation, 5 December http://theconversation.com/commonwealth-should-keep-final-say-on-environmentprotection-11047 Accessed 10 June 2014

Goodland, R. (2012). Responsible Mining: The Key to Profitable Resource Development, Institute for Environmental Diplomacy and Security. Burlington: University of Vermont.

Gunningham, N. \& Sinclair, D. (1999). Regulatory Pluralism: Designing Policy Mixes for Environmental Protection. Law and Policy, 21(1), 49-76.

Hart, S. (2010). Self-regulation, Corporate Social Responsibility, and the Business Case: Do they Work in Achieving Workplace Equality and Safety? Journal of Business Ethics, 92, 585-600.

Harvey, B. \& Nish, S. (2005). Rio Tinto and Indigenous Community Agreement Making in Australia. Journal of Energy and Natural Resources Law, 23 (4), 499-510.

Hickel, J. (2012) A Short History of Neoliberalism (And How We Can Fix It). New Left Project, http://www.newleftproject.org/index.php/site/article_comments/a_short_history_of_n eoliberalism_and_how_we_can_fix_it Accessed 12 June 2014

Hilson, G. (2013). The mining boom in Malawi: implications for community development. Community Development Journal, 48(3), 377-390.

Horta, K. (2012). Public-Private Partnership and Institutional Capture: The State, International Institutions and Indigenous Peoples in Chad and Cameroon. In S. Sawyer \& E.T. Gomez (Eds.) The Politics of Resource Extraction: Indigenous 
Peoples, Multinational Corporations, and the State (pp. 204-29). Basingstoke:

Palgrave Macmillan.

Hudbay Minerals (2013). 'Ethics and Human Rights'

http://www.hudbayminerals.com/English/Responsibility/Ethics-and-Human-

Rights/default.aspx Accessed 14 January 2013

Hume, M. (2012). Enbridge’s ‘errata’ on caribou could prove a costly error. The Globe and Mail, 12 November, S1 - S2.

ICMM (International Council on Mining and Metals). (2011). Good Practice Guide:

Indigenous People and Mining. London: ICMM.

http://www.icmm.com/library/indigenouspeoplesguide

IFC (International Finance Corporation). (2012a). IFC Performance Standards on

Environmental and Social Sustainable and Social Sustainability. IFC

http://www1.ifc.org/wps/wcm/connect/c8f524004a73daeca09afdf998895a12/IFC_Per formance_Standards.pdf?MOD=AJPERES

IFC (2012b). Policy on Environmental and Social Sustainability, IFC

http://www1.ifc.org/wps/wcm/connect/7540778049a792dcb87efaa8c6a8312a/SP Eng lish_2012.pdf?MOD=AJPERES

Kagan, R.A., Gunningham, N. \& Thornton, D. (2003). Explaining Corporate Environmental Performance: How Does Regulation Matter. Law \& Society Review, 37 (1), 51-89.

Kirchoff, D. \& Tsuji, J.S. (2014). Reading between the lines of the 'Responsible Resource Development' rhetoric: the use of omnibus bills to 'streamline' Canadian environmental legislation. Impact Assessment and Project Appraisal, 32(2), 108-120.

KLC (2011). Agreements. http://klc.org.au/agreements/ Accessed 23 March 2011.

Langton, M., Mazel, O., Palmer, L., Shain, K. \& Teehan, M. (Eds.). (2006). Settling with Indigenous People. Sydney: The Federation Press.

Lowe, N., \& Morton, B.J. (2008). Developing Standards: The Role of Community Benefits Agreements in Enhancing Job Quality. Community Development, 39(2), 23-35.

McLeod, P. (2012) 'Ottawa axes fisheries staff, offices’, Herald News, June 27 http://thechronicleherald.ca/canada/111543-ottawa-axes-fisheries-staff-offices Accessed 16 January 2012

Mulvihill, P.R., \& Jacobs, P. (1998). Using Scoping as a Design Process. Environmental Impact Assessment Review, 18, 351-69. 
Novaes, R.L.M. \& de Franca Souza, R. (2013). Legalizing environmental exploitation in Brazil: the retreat of public polciies for biodiversity protection. Tropical Conservation Science, 6(4), 477-483.

Nwapi, C. (2011). Legal and Policy Responses to Environmental Offences in Relation to Alberta Oil Sands. Resources, No. 115, 1-9.

O’Faircheallaigh, C. (2000). Negotiating Major Project Agreements: The 'Cape York Model'. Canberra: Australian Institute for Aboriginal and Torres Strait Islander Studies.

O’Faircheallaigh, C. (2002). Implementation: The Forgotten Dimension of AgreementMaking in Australia and Canada. Indigenous Law Bulletin, 5, 14-17.

O’Faircheallaigh, C. (2013a). Community Controlled Impact Assessment, Impact and Benefit Agreements and World Bank Policies on Indigenous Peoples: Briefing Paper for the Bank Information Centre http://www.bicusa.org/wp-content/uploads/2013/11/BICCommunityCIA-IBAs-WorldBankSafeguards-Brief-11-12-13.pdf Accessed 3 February 2013

O’Faircheallaigh, C. (2013b). Community Development Agreements in the Mining Industry: An Emerging Global Phenomena. Community Development, 44, 222-38.

RDS (Royal Dutch Shell PLC) (2012). Sustainability Report 2011. Rotterdam: Royal Dutch Shell PLC.

Sarker, T.K. (2013). Voluntary codes of conduct and their implementation in the Australian mining and petroleum industries: is there a business case for CSR? Asian Journal of Business Ethics, DOI 10.1007/s13520-012-0027-3

Sawyer, S., \& Gomez, E.T. (Eds.)(2012). The Politics of Resource Extraction: Indigenous Peoples, Multinational Corporations, and the State. Basingstoke: Palgrave Macmillan.

Schneiders, L. (2013) Qld and WA botch two big projects. Australian Financial Review, 16 January.

Salomons, G. H. \& Hoberg, G. (2013) Setting boundaries of participation in environmental impact assessment. Environmental Impact Assessment Review, http://dx.doi.org/10/1016/j/eiar.2013.11.001

Sinclair, D. (1997). Self-Regulation Versus Command and Control? Beyond False Dichotomies. Law \& Policy, 19(4), 530-559.

Steinzor, R., Glicksman, R.L. \& Havemann, A. (2014). EPA’s Retreat from Enforcement Will Harm Chesapeake Bay. Centre for Progressive Reform 
http://progressivereform.org/articles/EPA_StrategicPlan_IssueAlert_1402.pdf

Accessed 17 June 2014

Superior Court of Ontario 2012. Court File No. CV-10-411159.

http://www.chocversushudbay.com/wp-content/uploads/2010/11/Second-Amended-

Fresh-as-Amended-Choc-v.-HudBay-FILED.pdf Accessed 14 January 2013

Van Rooij, B. (2010) 'Greening Industry Without Enforcement? An Assessment of the World

Bank’s Pollution Regulation Model for Developing Countries. Law \& Policy, 31(1), 127-152.

World Bank. 2011. Implementation of the World Bank's Indigenous Peoples Policy A

Learning Review (FY 2006-2008). Washington D.C.: World Bank OPCS Working

Paper, August 2011.

World Bank. 2013a. OP 4.10July, 2005 - Indigenous Peoples, Revised April 2013.

Washington D.C.: World Bank.

Wright, J.S.F. \& Head, B. (2009). Reconsidering Regulation and Governance Theory: A

Learning Approach. Law \& Policy, 31(2), 192-216.

Xstrata (2013). Socio-economic benefits. http://www.xstrata.com/sustainability/socioeconomic-contributions/ Accessed 17 January 2013

Yi-chong, X. \& Bahgat, G. (Eds.) (2010) The Political Economy of Sovereign Wealth Funds. London: Palgrave Macmillan.

\footnotetext{
${ }^{1}$ In some cases technological advance allows development of resources in physically remote regions, for example natural gas in deep water offshore from the Kimberley Coast of Western Australia. In others it allows exploitation of 'unconventional' resources close to major population centres, for example shale gas in the United States.

${ }^{2}$ A third approach is to allow private markets to determine the allocation of the economic benefits, and the burden of environmental and social costs, associated with extractive industries. While not without its advocates in academia and industry, no government in a major mineral producing state has pursued this approach over an extended period of time. Indeed a number of countries that had moved in its direction in response to 'guidance' from the World Bank and the International Monetary Fund have recently retreated from it (see for example Fuentes 2011, pp. 92-9). The unwillingness of states to cede control of mining to the market reflects political pressure to guarantee an economic return to nations from resources seen as part of their birth right, and to respond to the negative environmental and social impacts associated with unconstrained private sector resource extraction (see for instance Horta 2012).

${ }^{3}$ There is a huge literature that addresses the issue of what constitutes 'corporate social responsibility' or 'corporate social performance', and much debate about how CSR initiatives should be defined and understood and regarding their significance. It is beyond the scope of the article to address these debates in detail. Rather the goal is to identify core characteristics and consequences of corporate initiatives as these relate to community development impacts.

${ }^{4}$ Some CDAs may take the form of Memoranda of Understanding or other non-binding instruments.

Particularly in the contemporary periods, most either state explicitly that they are intended to be legally binding,
} 
or take a form that clearly indicates that they are contractual in nature and so enforceable in a court. In any case, in this context my argument relates to CDAs that are legally binding.

${ }^{5}$ For example in Australia there is a requirement under the Commonwealth Native Title Act for applicants for mining leases to seek agreement with Indigenous people who hold or claim inherent rights to land ('native title'), while under many comprehensive land claim settlements in Canada there is a requirement for 'Impact and Benefit Agreements' to be in place before resource projects can proceed. In both cases there is enormous variability in the provisions negotiated across individual agreements. 